\title{
PENEGAKAN DEMOKRASI DALAM PENYELENGGARAAN PEMILU/PEMILUKADA PRESFEKTIF HUKUM KETATANEGARAAN DI INDONESIA
}

\author{
Sugianto \\ Fakultas Syariah dan Ekonomi Islam \\ Institut Agama Islam Negeri Syekh Nurjati Cirebon \\ Email: sugiantoaphi@gmail.com
}

\begin{abstract}
ABSTRAK
Penyelenggaraan Pemilihan Umum / Pemilukada di Indonesia masih adanya kepentingan politik yang cukup tajam " dalam hal ini karena tarik ulur dalam pembahasan Regulasi sebagai landasan Hukum Penyelenggaraan Pemilu dalam rangka mewujudkan pemilu yang dermokratis.

Masih adanya Kepentingan Politik dalam Pemilihan Umum / Pemilihan kepala daerah secara konstitusional berarti memilih kepala daerah atas aturan yang berdasarkaan konstitusi.Ada 2(dua) hal yang penting dicatat.Pertama, ketika pemilihan kepala daerah itu sendiri sedang berlangsung, calon kepala daerah atau tim suksenya tidak boleh melakukan hal-hal yang bertentangan dengan semangat dan jiwa konstitusi.
\end{abstract}

Kata Kunci : Pemilu/ Pemilu kada dan Demokrasi

\begin{abstract}
Implementation of General Election / Election in Indonesia is still a sharp political interest "in this case because of the drag on the discussion of the Regulation as the foundation of the Law of Election Operation in order to realize a dermocratic elections.

The existence of Political Interest in General Election / Regional Head Elections constitutionally means choosing the regional head for the constitution-based rules. There are 2 (two) important things to note. Firstly, when the election of the head of the region itself is ongoing, the candidate of the regional head or team suksenya should not do things that are contrary to the spirit and spirit of the constitution.
\end{abstract}

Keywords: Election / Elections and Democracy 



\section{A. Reformasi dan Pemilihan Kepala Daerah.}

Perubahan Politik dalam Sistem ketata negaraan Indonesia terjadi secara fundamental sejak gerakan Reformasi di gulirkan tahun 1998 dengan lengsernya rezim Soeharto sebagai Presiden Republik Indonesia.

Gerakan reformasi tampaknya menjadi tonggak yang begitu monumental untukmelakukan perubahan yang sangat mendasar dalam bidang praktekpolitik maupun norma ketatanegaraan.Perubahan dalam norma ketatanegaran terjadi ketika gagasan tuntutan perubahan UUD 1945 yang sangat disakralkan pada masa Orde Baru, akhirnya direspon oleh Majelis Permusyawarana Rakyat (MPR). MPR yang ketika itu masih berkedudukan sebagai lembaga tertinggi negara dan merupakan lembaga yang sering disebut sebagai pemegang kedaulatan rakyat dan merupakan penjelmaan seluruh rakyat Indonesia akhirnya benar-benar merealisasikan tuntutan rakyat dalam gerakan reformasi yaitu amandemen terhadap UUD 1945. ${ }^{1}$ Mengingat banyaknya norma ketatanegaran yang perlu diamandemen, maka MPR melakukannnya melalui sidang tahunan, yang digelar setiap tahun, dan amandemen terhadap UUD 1945 terjadi pada tahun 1999, 2000, 2001, dan 2002.

Dalam bidang pemilihan kepala daerah (pilkada), terjadi perubahan norma yang cukup mendasar. Pada UUD 1945 Sebelum Amandemen, pemilihan kepala daerah tidak diatur. Aturan terhadap Pilkada diserahkan pada undang-undang

pelaksanaannnya.Akibatnya, pilkada pada masa UUD 1945 sebelum Amandemen, sangat rawan diterjemahkan sesuai kepentingan politik

Gaffar, Janedjri M., 2013. Demokrasi dan Pemilu di Indonesia, cetakan pertama, Jakarta: Konstitusi Press. rezim yang berkuasa.Maka tidak mengherankan jika Presiden Soeharto waktu itu mempunyai wewenang yang lebih besar untuk memilih kepala daerah dari calon yang diajukan oleh DPRD..

Sekarang era pilkada telah bergeser seiring dengan adanya I norma dalam UUD RI 1945 (sebutan terhadap UUD 1945 hasil amandemen), dimana dalam Pasal 18 ayat (4) disebutkan bahwa Gubernur, Bupati, dan Walikota masingmasing sebagai kepala daerah provinsi, kabupaten dan kota dipilih secara demokratis. Norma ini muncul pada saat MPR melakukan amandemen yang kedua tahun 2000. Sementara itu, pada tahun 1999, dibidang pemerintahan daerah, telah ada UU No 22 tahun 1999 yang merubahUU No 5 Tahun 1974 tentang Pemerintahan Daerah. Keberadaan UU No 22 Tahun 1999 merupakan tonggak reformasi di bidang penyelenggaraan pemerintahan di daerah dengan asas desentralisasi yang kuat, termasuk posisi DPRD yang juga diperkuat. Dalam UU No 22 Tahun 1999 Gubernur, Bupati, dan Walikota dipilih oleh DPRD. Tidak ada otoritas Presiden untuk mengintervensi pemilihan kepala daerah, karena proses pemilihan diserahkan pada DPRD secara demokratis.

Akibatnya dalam praktek, dapat ditemui pemilihan kepala daerah yang sesungguhnya bertentangan dengan esensi demokrasi, seperti politik uang dalam menggalang dukungan di internal DPRD sehingga terpilihlah kepala daerah yang tidak kapabel menjadi seorang pemimpin. Pemilihan kepala daerah oleh DPRD ketika itu juga sering dinilai sebagai pemilihan yangmeninggalkan aspirasi rakyat, sebab rakyat tidak mempunyai posisi penting dalam proses pemilihan calon pemimpinnya. Pencalonan maupun proses pemilihan sepenuhnya menjadi otoritas partai politik yang mempunyai wakilnya di DPRD sehingga dapat dipastikan, partai yang 
menguasai kursi di DPRD (partai mayoritas) secara politik mempunyai legitimasi dan kekuatan untuk mencalonkan I kadernya dan peluang kader tersebut untuk terpilih sangat besar, I padahal belum tentu kader tersebut berkualitas dan mempunyai kemampuan untuk memimpin.

Pemilihan kepala daerah secara konstitusional berarti memilih kepala daerah atas aturan yang berdasarkaan konstitusi.Ada 2(dua) hal yang penting dicatat.Pertama, ketika pemilihan kepala daerah itu sendiri sedang berlangsung, calon kepala daerah atautim suksenya tidak boleh melakukan hal-hal yang bertentangan dengan semangat dan jiwa konstitusi, seperti memberi stimulus baik berupa barang, jasa maupun uang yang dapat berindikasi adanya maksud bahwa penerima akan terdorong untuk memilihnya. Hal-hal seperti ini memang tidak tercantum dalam konstitusi, akan tetapi hal itu dapat mengarah pada tindakan yang berkategori politik uang yang dilarang oleh hukum dan hal itu sangatlah tidak demokratis .Kedua, pemilukada yang konstitusional, tidak saja secara gramatika dimaknai berdasar apa yang tertulis dalam konstitusi akan tetapi juga sesuai dengan hakekat konstitusi, yaitu bahwa konstitusi pada hakekatnya membatasi kekuasaan agar rakyat tidak dirugikan, sehingga ketika seorang terpilih menjadi kepala daerah maka dalam menjalankan kekuasaannya harus tunduk pada pembatasan-pembatasan. Pembatasan ini tidak saja dalam konstitusi tetapi juga melalui undang-undang organiknya. Akan tetapi sungguh ironis, dalam prakteknya, tidak semua kepala daerah yang terpilih menurut dasar aturan konstitusi, dapat menjalankan kekuasaannya sesuai amanah undang-undang, karena ada kepala daerah yang melakukan abuse of power dalam menjalankan kekuasaan, dengan melakukan hal-hal yang merugikan rakyat, seperti korupsi. ${ }^{2}$

Kini Pemilihan kepala Daerah telah memasuki era baru semenjak UU No 22 tahun 1999 dirubah melalui UU No 32 tahun 2004.Dalam UU yang disebut terakhir, kepala daerah dipilih secara langsung oleh rakyat.Dari segi siapa yang berhak mencalonkan, calon kepala daerah dicalonkan oleh partai politik, atau gabungan partai politik, dan calon perseorangan (independent). Ketentuaan tentang calon independent ada setelah Mahkamah Konstitusi membolehkann adanya calon perseorangan melalui Judicial Review atas UU No 32 tahun 2004 dan DPR kemudian merubah UU No 32 tahun 2004 menjadi UU NO 12 tahun 2008.

\section{B. PEMILUKADA DAN SISTEM POLITIK DEMOKRATIS}

Sistem politik demokratis ciri khasnya terletak pada tatanan demokratis yang melandasi penguasa sehingga elemen-elemen demokrasi tidak saja menjadi norma bernegara tetapi secara empirik bekerja sesuai dengan koridor demokrasi.

Sebuah sistem politik yang demokratis akhirnya menjadi pilihan walaupun memerlukan sejumlah prasyarat dan prasyarat tersebut tidak mudah untuk dipenuhi karena sejumlah faktor seperti tingkat pendidikan warga masyarakat, tingkat pendidikan dan kesadaran politik masyarakat, komitmen penyelenggara kekuasaan untuk menciptakan system poltik yang demokratis, sampai pada faktor adanya peraturan hukum yang dapat menjadi instrument bagi pelaksanaan sistem politik demokratis.

Secara teoritik, Diomond, Linz, dan Lipset mengartikan demokrasi

2 Mulyadi, Dedi,2013. Perbandingan Tindak Pidana Pemilu Legislatif - dalam perspektif hukum di Indonesia, cetakan Kesatu, Bandung : Refika Aditama. 
sebagai suatu sistem pemerintahan yang mempunyai 3 (tiga) syarat, yaitu :

1. Kompetisi yang sungguh-sungguh meluas diantara individu individu dan kelompok-kelompok organisasi

untukmemperebutkan jabatanjabatan pemerintahan yang memilikikekuasaan efektif, pada jangka waktu yang reguler, dan tidakmelibatkaan penggunaan daya paksa

2. Partisipasi yang melibatkan sebanyak mungkin warga Negaradalam pemilihan pemimpin atau pembuatan kebijakan

3. Kebebasan politik dan sipil yaitu kebebasan berbicara, kebebasan pers, kebebesan membentuk dan bergabung ke dalam organisasi, yang cukup untuk menjamin integritas kompetissi dan partisipasi politik.

Dari 3 (tiga) syarat tersebut, jika pilkada dimaksudkan untuk 'membentuk pemerintahan yang demokratis, maka kontestan harus dibuka untuk semua warga negara yang memenuhi syarat yang diatur melalui undang-undang.Para kontestannya (peserta pilkada) berjuang secara fair dan sportif.Para kontestan juga dilarang menggunakan cara-cara paksaan maupun kekerasan untuk memaksa seseorang memberikan suaranya pada kontestan tertentu. Dalam UU No 32 tahun 2004 tentang Pemerintahan daerah sebagaimana telah dirubah menjadi UU No 12 tahun 2008 tentang Pemerintahan daerah, warga masyarakat yang mempunyai hak pilih juga harus terlibat memberikan suaranya pada proses pemilihan. Partisipasi warga dalam pemilhan diharapkan tinggi sehinggga hasil pemilihan mempunyai legitimasi kuat. Namun demikian partisipasi warga masyarakat dalam memilih harus tetap berada pada koridor kebebasan politik dan kebebasan sipilnya, tanpa takut akanintimidasi, tetap mempunyai rasa aman. Para kontestan/peserta pemilihan maupun sesama warga masyarakat harus menghargai kebebasan politik dan kekebasan sipil baik terhadap sesama kontestan maupun terhadap sesama warga masyarakat. Selama tidak ada jaminan terhadap kebebasan ini, maka pemilukada akanjauh dari demokratis. Akan tetapi syarat normatif tersebut kadang diabaikan baik oleh kontestannya maupun oleh para pendukungnya sehingga berbagai kecurangan pemilukada begitu nampak, dan ini tentunya merupakan ancaman bagi demokrasi.

Pemilhan Kepala Daerah dikatakan demokratis jika memenuhi beberapa syarat, diantaranya syarat sebagaimana juga diberlakukan untuk Pemilu legislatif secara umum yaitu:

1) Adanya pengakuan hak pilih universal. Semua warga Negara yangberhak memilih, tidak boleh didiskriminasi atas dasar ideology danpolitik

2) Adanya wadah bagi pluralitas aspirasi masyarakat pemilih sehinggamasyarakat memiliki alternative pilihan saluran aspirasi politiknya.

3) Tersedia mekanisme rekruitmen politik yang demokratis

4) Adaanya kebebasan pemilih untuk menentukan pilihannya

5) Adanya panitia pemilih yang independent

6) Adanya keleluasaan kontestan untuk berkompetisi secara sehat

7) Penghitungan suara yang jujur

8) Netralitas birokrasi

Dalam berdemokrasi, hendaknya semua pihak tetap menjunjung nilai kejujuran, menghargai sesama, dan taat pada aturan. Dalam Pemilukada tentu tidak ada pasangan calon kepala daerah yang ingin kalah, semua pasti ingin menang, akan tetapi ibarat pertandingan, pada akhirnya hanya akan ada 1 (satu) pasangan calon yang akan menjadi pemenang. Sudah 
barang tentu yang menang tidak boleh sewenang wenang, yang kalah tidak boleh marah dengan berbagai ulah.Jika merasa diperlakukan tidak adil dan mempunyai cukup bukti ada kecurangan yang menimbulkan sengketa, ajukan ke Mahkamah Konstitusi RI (MKRI). ${ }^{3}$

\section{MENEGAKKAN DEMOKRASI DAN KONSTITUSIONALITAS PEMILUKADA}

Mahkamah Konstitusi lahir tidak saja untuk menjaga dan menegakan konstitusi, akan tetapi Mahkamah Konstitusi (MK) lahir juga untuk menegakkan demokrasi. Oleh karena Pemilihan Kepala (Pemilukada) kini masuk ke ranah rezim pemilihan Umum, maka secara konstitusional, kewenangan Mahkamah Konstitusi (MK) menyelesaikan sengketa hasil pemilukada ada pada Pasal 24 C ayat (1) UUD RI1945 yaitu : Mahkamah Konstitusi berwenang mengadili pada tingkat pertama dan terakhir yang putusannya bersipat final untuk menguji Undang-undang dibawah UUD, - Memutus sengketa kewenangan lembaga Negara yang kewenangannya diberikan oleh UUD,- Memutus pembubaran Partai politik,- Dan memutus perselisihan tentang hasil pemilihan umum. Dan kemudian legitimasi formal yang secara eksplisit menyebut kewenangan MK dalam sengketa Pemilukada disebut dalam Pasal 236C UU No 12 Tahun 2008 tentang

Perubahan kedua Atas Undang-Undang Nomor 32 tahun 2004 tentang Pemerintahan Daerah,Bahwa kewenangan penyelesaian sengketa Pemilukada diberikankepada Mahkamah Kostitusi (MK RI) paling lama 18 bulan sejak Undang-undang ini di undangkan,"maka untuk itu sejak Undang-undang no 15 tahun 2011 tentang Penyelenggaraan pemilu dalam pasal 1 ayat 4 "Bahwa

Gaffar, Janedjri M., 2013. Politik Hukum Pemilu, cetakan kedua, Jakarta: Konstitusi Press.
Gubernur,Bupati, Walikota sebagai kepala Daerah dipilih secara Demokratis dalam Negara kesatuan Republik Indonesia (NKRI), Artinya Penyelesaian sengketa pemilihan gubernur, Bupati / walikota sebagai kepala daerah yang dipilih secara demokratis seharusnya tidak lagi oleh Mahkamah Konstitusi ( MK RI) dikembalikan pada Mahkamah Agung (MA).

Walaupun tidak-semua perkara itu menunjukan ada pelanggaran hak konstitusional

warga negara atau pemohon yang bersifat struktural, sistematis dan massif dalam penyelenggaraan Pemilukada.

Kewenangan kedua lembaga Negara :

Mahkamah Agung RIMahkamah Konstitusi

UU no 48 tahun 2009

UU no 24 th 2003 diganti UU no 8 tahun 2011 tentang MK RI .

Kewenangannya

Kewenangannya :

1. Mengadili pada tingkat kasasi 1. Menguji UU terhadap UUD 1945

Terhadap putusanyang diberikan 2. Memutus sengketa lembaga

Pada tingkat terakhiroleh pengadilan Negara yg kewenangannya

Pada semua lingkungan peradilan diberikan oleh UUD 45.

Dibawah Mahkamah agung. 3.

Memutus pembubaran

Partai politik.

2. Menguji peraturan peundang4. Memutus perselisihan ttg-

Undangan dibawah Undangundang. Hasil pemilu.

3. Melakukan pengawasan tertinggi 5. Wajib memberikan putusan atas Atau perbuatan pengadilan dalam pendapat DPR bahwa Presiden/-

Lingkungan peradilan yang Wapres diduga telah

Berada dibawahnya. Melakukan pelanggaran 
Hukum berupa penghianatan

Negara,korupsi, penyuapan,

Dsb.

Pada dasarnya setiap daerah baik provinsi, kabupaten, maupun kota menurut UUD Negara RI tahun 1945 hanya memiliki "Kepala Daerah" yaitu 'Gubernur' untuk daerah provinsi, 'Bupati' untuk daerah kabupaten, dan 'Walikota' untuk daerah kota. Dalam prespektif 'recruitmen' kepala daerah pada pasal 18 ayat (4) UUD Negara RI Tahun 1945 hanya dilakukan secara demokratis dan tidak menggunakan prinsip 'secara langsung' sebagaimana pemilihan Presiden dan Wakil Presiden sebagaimana ditentukan dalam pasal 6A ayat (1) UUD Negara RI Tahun 1945, tetapi melalui pasal 56 ayat (1) UU Nomor 12 Tahun 2008 bahwa kepala daerah dan wakil kepala daerah dipilih dalam satu pasangan calon yang dilaksanakan secara demokratis berdasarkan asas LUBER (Langsung umum bebas rahasia ,jujur dan adil ), Dalam Undang-undang no 15 tahun 2011 Pasal 1 ayat 2 \& 3 " bahwa DPR,DPD,DPRD dan Presiden /wakil presiden merupakan pemilihan umum (pemilu) berbeda dengan gubernur, bupati/walikota sebagai kepala Pemerintah daerah merupakan pemilihan (pasal 1 ayat 4$){ }^{4}$

Dalam prespektif pemilihan Kepala Daerah, juga tidak dapat menghindarkan dari situasi transisi demokrasi yang terjadi di Indonesia, karena memang Pemilihan Kepala Daerah secara langsung baru dimulai setelah perubahan UUD 1945.Pemilihan Kepala Daerah yang semula dipilih melalui prinsip perwakilan dipilih melalui prinsip perwakilan (DPRD) dan berubah menjadi pemilihan langsung adalah suatu perubahan yang

${ }^{4}$ Undang-Undang Nomor 15 Tahun 2011 tentang Penyelenggara Pemilihan Umum drastis, karena rakyat secara langsung dihadapkan pada keputusan untuk memilih. Lompatan perubahan dalam Pemilhan Kepala Daerah ini, tentu akan membawa dampak positif dan negative. Dampak positif, justru pada upaya pendewasaan masyarakat dalam berdemokrasi, baik dalam memilih pemimpinnya, maupun dalam menentukan arah kebijakan pemimpinnya dalam kerangka mewujudkan kesejahteraan bersama. Proses ini jika dikawal oleh instrument yang sesuai, peneyelenggara yang independen dan berintegrasi, akan melahirkan pimpinan dan kebijakan yang memenuhi prinsip 'legal, legitimate, dan competence.

Organ legislative adalah lembaga parlemen, organ eksekutif adalah birokrasi pemerintahan, sedangkan organ judikatif adalah birokrasi aparatur penegakan hukum yang mencakup kepolisian, kejaksaan dan pengadilan. Semua organ harus dihubungkan dengan hirarkinya masing-masing mulai dari yang tertinggi sampai yang terendah, yaitu terkait dengan aparatur tingkat pusat, tingkat provinsi, dan tingkat kabupaten/kota. Keseluruhan elemen, komponen, hirarki dan asoek-aspek yang bersifat sistemik dan saling berkaitan satu sama lain itulah tercakup pengertian system hukum yang harus dikembangkan dalam kerangka Negera Hukum Indonesia berdasarkan UUD 1945.

\section{PENYELESAIAN SENGKETA PEMILU}

Munculnya pelanggaran-pelanggaran Pemilihan kepala daerah yang tidak terkendali, dan bahkan tidak dapat diselesaikan pada setiap tahapan proses pelaksanaan pemilihan kepala daerah, timbul gagasan pembentukan peradilan Pemilihan kepala daerah pada setiap daerah. Peradilan Pemilu ini dimaksudkan sebagai penyelesaian masalah atau sengketa pada setiap tahapan proses Pemilihan kepala daerah, agar setiap tahapan tersebut terdapat kepastian 
hukum. Faktanya, setiap tahapan proses masih rawan digugat ke lembaga peradilan dalam hal ini Mahkamah Konstitusi, karena hal-hal yang diputuskan oleh lembaga yang berwenang pada tahapan tersebut dianggap tidak memberikan jaminan kepastian. Selain Mahkamah Konstitusi yang diberikan oleh UUD 1945 menyelesaikan hasil pemilu sesuai pasal $24 \mathrm{c}$, digagas agar terdapat pula lembaga peradilan yang dapat menyelesaikan sengketa atau pelanggaran pada tahapan proses Pemilihan kepala daerah . Di usulkan pada Mahkamah Konstitusi (MK ) diawal tahun 2014 seharusnya tidak lagi menyelesaikan sengketa pemilihan kepala daerah, hal tersebut harus dikembalikan pada Mahkamah Agung (MA RI) untuk dapat menyelesaikan sengketa hasil pemilihan gubernur,Buati/walikota sebagai kepala daerah.

Mekanisme penyelesaian sengketa pemilihan umum ( Elektoral Dispute Resolution" EDR" artinya)hal tersebut dapat dlakukan dengan dua cara yaitu :Melalui jalur formal dan informal. ${ }^{5}$

(EDR Artinya dapat berupajalur procedural yaitu melalui pengadilan atau semacam komsi bentukan khusus yang menangani masalah pemilihan umum dan / melalui Negosiasi. Dalam rangka penegakan hukum penyelesaian sengketa pemilhan umum yaitu setidaknya harus dilakukan dengan 5 (lima ) cara :

1. Pemeriksaan oleh badan penyelenggara pemilu ( di usulkan pada DKPP dan / Bawaslu ).

2. Perlu dibentuk Pengadilan khusus dan / hakim khusus pemilu untuk menangani keberatan sengketa pemilu.

3. Penyelesaian masalah pemilu diserahkan pada pengadilan konstitusional
4. Penyelesaian masalah pemilihan oleh pengadilan tinggi/“" Mahkamah Agung“ untuk sengketa pemilihan Gubenur,Bupati/walikota dan

5. Untuk Penyelesaian sengketa hasil pemilu legislatip / Presiden \& wakil Presiden oleh MK RI.

Gagasan mengenai perlunya pembentukan peradilam pemilu yang akan menangani pelanggaran Pemilu pada tahap proses, disamping Mahkamah Konstitusi tetap sebagai lembaga Peradilan yang menyelesaikan sengketa hasil pemilu bagi DPR,DPD, DPRD, dan Pemilu Presiden/wakil presiden, menjadi relevan jika dihadapkan pada realitas politik, bahwa banyak terjadi pelanggaran pemilu yang tidak dapat diselesaikan oleh lembaga yang ada, kecuali Mahkamah Konstitusi. Dalam prespektif politik, gagasan ini rasional dan realistis, tetapi dari segi yuridis agaknya gagasan ini akan berhadap dengan ketentuan Pasal $24 \mathrm{C}$ ayat (1) UUD 1945. Dalam ketentuan Pasal 24 C ayat (1) UUD 1945 secara eksplisit menentukan bahwa kewenangan untuk memutus perselisihan hasil pemilu ada Mahkamah Konstitusi, sehingga apakah masih dimungkinkan membentuk badan peradilan lain yang khusus diberikan kewenangan untuk memutus pelanggaran pemilu, bahwa potensi permasalahan pemilihan umum dapat diklasipikasikan menjadi 3 kelompok seperti pelanggaran administrasi pemilu,Pelanggaran tindak pidana pemilu dan pelanggaran hasil sengketa pemilu. ${ }^{6} \mathrm{~s}$

Menurut Topo santoso menegaskan bahwa sengketa dalam penyelenggara an pemilu merupakan sebuah pelanggaran administrasi pemilu atau kasus ketidak puasan atas keputusan penyelenggara pemilu "hal ini kewenanagan DKPP (Dewan kehormatan penyelenggara

6 Sardini, Nur Hidayat, 2011. Restorasi Penyelenggaraan Pemilu di Indonesia, cetakan Pertama, Yogyakarta : Fajar Media Press 
pemilu). ${ }^{7} \quad$ Oleh karenanya istilah perselihan tentang Sengketa hasil pemilihan umum bagi DPR,DPD,DPRD \& Presiden /Wakil Presiden, dalam UUD 1945 pasal 24 c ayat 1 , merupakan bagian yang harus diselesikan oleh Mahkamah Konstitusi (MK RI ).

$$
\text { Menurut pendapat Penulis }
$$

(Pemateri)yang sudah dua kali mengikuti seleksi Hakim Mahkamah Konstitusi (MK RI) tahun 2009 \&Maret 2013 bahwa pernah menyampaikan pada saat uji kelayakan\&kepatutan (Piet and Profer tes ) Komisi III DPR RI di Jakarta menegaskan bahwa penyelesan sengketa hasil pemilihan kepala daerah (Gubernur,Bupati/walikota sebagai kepala daerah ) sejak UU no 12 tahun 2008 pasal 236 c Harus dikembalikan pada Mahkamah Agung (MA RI) bukan lagi kewenangan MK RI.

\section{Daftar Pustaka}

Gaffar, Janedjri M., 2013. Politik Hukum Pemilu, cetakan kedua, Jakarta: Konstitusi Press.

Gaffar, Janedjri M., 2013. Demokrasi dan Pemilu di Indonesia, cetakan pertama, Jakarta: Konstitusi Press.

Indonesia, Undang-Undang Nomor 15 Tahun 2011 tentang Penyelenggara Pemilihan Umum.

Lutfi, Mustafa, 2010. Hukum Sengketa Pemilukada di Indonesiagagasan perluasan kewenangan konstitusinal Mahkamah Konstitusi, cetakan Pertama, Yogyakarta: UII Press.

Mulyadi, Dedi,2013. Perbandingan Tindak Pidana Pemilu Legislatif dalam perspektif hukum di

${ }^{7}$ Topo santoso, makalah berjudul perselihan hasil pemilukada yang disampaikan pada diskusi terbatas pada Mahkamah Konstitusi tanggal 24 maret 2011.
Indonesia, cetakan Kesatu, Bandung : Refika Aditama.

Santoso, Topo, 2006. Penegakan Hukum Pemilu - praktik Pemilu 2004, kajian Pemilu 2009-2014, Jakarta : Perludem-US AID-DRSP.

Sardini, Nur Hidayat, 2011. Restorasi Penyelenggaraan Pemilu di Indonesia, cetakan Pertama, Yogyakarta : Fajar Media Press

Sahdan, Gregorius dkk, 2008. Politik Pilkada-tantangan merawat demokrasi, Yogyakarta: IPDKonrad Adenauer Stiftung 